\title{
Translating Gender into the Governmental Discourse: An Analysis of 'Unarthupattu' (The song of Awakening)
}

\section{DEEPA V}

This paper looks into the issues and concerns when a concept like 'gender' gets translated into governmental discourses. Taking 'Unarthupattu' as a case study, it analyses issues of representation, both textual and visual, in deploying gender as a category in governmental discourses. This paper explores how such usage reaffirms existing gender relations, ideologies and the established order.

Keywords: gender, discourse, representation, feminism

\section{Introduction}

Over the last few years, especially since the mid-90s, the term 'gender' has gained much currency in the governmental and non-governmental discourses. Terms like mainstreaming gender, gender development, gender budgeting and gender training have become popular in the public discourse of Kerala and have even become part of everyday life. With the mission of mainstreaming gender in the public discourse of Kerala, the governmental and nongovernmental organizations have undertaken to conduct gender training and other gender awareness programmes. For instance, Sakhi (the companion), a Trivandrum based resource centre for women, conducts every year a fifteen day course on gender, health and development for health activists and facilitators. Gender training is used as a tool to build up and strengthen gender perspective among women. ${ }^{1}$ The Kerala government, in order to create awareness, among persons and groups who are working among students has conducted a campaign - it includes a 30 minutes documentary called Unarthupattu 'song of awakening' and other gender awareness programmes in about 40 women's colleges. ${ }^{2}$ The campaign was spearheaded by Kerala State Women's Development Corporation (KSWDC). In order to facilitate the gender training, Sakhi has even come up with a gender training manual in Malayalam.

The term 'gender' made its entry into the development discourse in the 1980s as a substitute for the category 'women' as the latter conceived women

\footnotetext{
${ }^{1}$ Online: http://sakhikerala.org/Capacity Building pgms.html accessed on 05-01- 2012

${ }^{2}$ Online: http://www.kswdc.org/category/video-galleries/unarthupattu-song-awakening accessed on 10-03-2012
} 
as a homogeneous entity without any conflict of interests or concerns. ${ }^{3}$ However, it became popular after the fourth World Conference on Women held in Beijing in 1995. The Beijing Declaration as well as Platform for Action (1995) put forward mainstreaming gender as its objective resulting in international and national level plans and schemes for gender mainstreaming. ${ }^{4}$

Though 'gender' was proposed to put 'women' into their socio-economic, political and cultural contexts and to address the power equations involved in gender relations in the developmental discourse it lost its political nature and has become a neutral term for referring men and women. Thus, closing the enormous possibilities that gender as an analytical category opened up in the feminist discourse in the 1980s.

The binary between sex/gender has been a matter of debate within the feminist circle. While sex is conceived as biologically determined, gender is culturally constructed. However such distinctions have also been criticised in the 1990 s by feminist scholars. The binary between man/woman and feminine/masculine have also been challenged as it 'implicitly retains the belief in a mimetic relation of gender to sex whereby gender mirrors sex' (Butler 1990). According to Butler, gender is not mere interpretation of sex or the cultural meanings that the sexed bodies assume. Rather, "gender designates the very apparatus of production which establishes the sexes". Gender, according to her is "the "discursive/cultural means by which "sexed nature" or "natural sex" is produced and established as "prediscursive" prior to culture, a politically neutral surface on which culture acts" (1990: 7).

However, in the governmental discourse of Kerala 'gender' gets translated as 'women', thus depoliticising and neutralising its possibilities. If gender is deployed in the feminist discourse to critique the homogeneous universal category 'women'; to challenge the binary relation between man/woman and to radically reconstitute the subject of feminism, in the governmental discourse it gets translated as a substitute for the category women, to reaffirm the binary man/woman and thus reaffirming the established order and heteronormative norms.

According to one of the studies conducted by Sakhi:

Where talking about 'women' implied awareness of women's marginalization and subordination, the term gender is used in a neutral way, referring to both men and women. The issue of relations of power is easily removed and remains unaddressed. Thus, to a great extent the gender language has implied a depoliticization of women's issues in development, turning gender into a matter of planning and monitoring and not of understanding

\footnotetext{
${ }^{3}$ Review of women's component plan in Kerala. A study conducted by Sakhi a resource center for women located in Trivandrum.

${ }^{4}$ Online: http:// www.un.org/womenwatch/daw/Beijin/platform/plat1.htm\#statement.
} 
the power equations underlying such relations and the oppression based on that. ${ }^{5}$

However, even in the above criticism, 'women' is considered as a homogeneous category and the issue of marginalization and subordination within the category 'women' is ignored. Thus, men and women as two distinct groups (based on the biological differences) with each having particular characteristics, interests and issues is reaffirmed. As a result, rather than dismantling the binary division man/woman (which was in fact why the concept gender was brought in the feminist discourse in 1980s) the governmentalized 'gender' has reaffirmed it. Besides, the issues usually projected as gender issues - dowry, domestic violence etc. were middle-class women's issues.

In this paper, an attempt is made to problematize the use of 'gender' in the governmental discourses and to see how the State has redeployed the category 'Women'-middle class, educated, modern and so on- which is central to both the mainstream feminist discourses as well as governmental discourses. Unarthupattu is chosen as it involves two layers of translation- textual and visual. For the analytical purpose I have used Roman Jakobson's concepts of intralingual translation and intersemiotic translation.

Jakobson in his paper "On linguistic aspects of translation" classifies translation into three categories- intralingual, interlingual and intersemiotic translations. According to him intralingual translation is "an interpretation of verbal signs by means of other signs of the same language" (2008: 138). On the other hand, intersemiotic translation is "an interpretation of verbal signs by means of signs of nonverbal sign systems"(2008: 139). Here, the concept of 'gender' has undergone a translation from the domain of feminist and other academic discourse into the governmental discourse, thus, producing a different interpretation of the concept. The ways in which 'gender' is being appropriated into the governmental discourse become clear and obvious in its visual representation, Unarthupattu. The paper also attempts to look at how translation as a political activity reaffirms certain norms and ideologies.

Unarthupattu is a 30 minutes short film which was part of the Gender Awareness Campaign spearheaded by Kerala State Women's Development Corporation in collaboration with Darpana Communications. It is claimed to be conducted in women's colleges across the state. According to the report it has reached 40 women's colleges, covering 20000 female students. It contains seven parts. Each part deals with one issue. The issues dealt in here include educational stress, sexual exploitation, cyber-crimes, domestic violence and dowry issues.

The first part deals with educational stress and peer pressure. It's titled "Dhanya's Story". Dhanya is a studious and brilliant student in the school and

\footnotetext{
${ }^{5}$ Review of women's component plan in Kerala. A study conducted by Sakhi a resource centre for women located in Trivandrum.
} 
her teachers, friends and parents expect her to get a rank in the coming examination. Dhanya's father had already gone to see Bank manager to enquire about education loan. Dhanya studies till late night and has bad dreams about the examination in sleep. She wakes up from the dream and thinks how her father will scold her if she loses even one mark and how her teachers will be disappointed. She gets up and starts skipping through the pages very tensed and nervous.

The second part deals with sexual exploitation. It's titled Annie's story. Opening scene shows two families having dinner party. The host is Annie's family and the guests are George and his wife. Annie hesitates to come down but she joins them later upon her father's demand. Suddenly George proposes a plan to go to Kodaikkanal. Everyone is happy about the trip except Annie. The next morning George comes to Annie's house. Seeing Annie sitting in sofa and listening to music, he goes close to her and touches her on her neck. Annie gets startled and turns back. George goes to her mother and tells her that he can arrange a chance for Annie to anchor in some TV programme. Hearing this, her mother is very happy. She encourages Annie to go with George uncle. Annie denies. That night Annie approaches her mother crying and tells her what has happened. She consoles Annie.

Part three discusses issues of misuse of mobile phones. It is titled Sraddha's story. Sraddha gets a phone call from Aswin, her boyfriend, in the morning saying he lost his mobile. Suddenly she becomes very much worried and calls Aswin and asks whether he lost the mobile which had her photos. He says he has deleted it long back. She goes to college worried and tensed. Sraddha reaches college. On the way to class room she meets her teacher and friends. They were all looking in to their mobile and laughing at her. She hears comments on her- doesn't she have sense?, how could she do this? She is shameless and dirty, etc. Suddenly she gets up and runs out of the class room shouting "that's not me", "that's not me". She faints down and is hospitalized.

The next four parts discusses domestic violence, dowry, etc. All the four parts have two sessions. The first session is colourful where a girl talks about her dreams about family life, marriage, children, etc. In the next session which is in black and white, her life after marriage is shown. Part four is titled as 'Ideal Husband'. One girl talks about how her husband should be. The second session shows her married life after a few years. She and her two children are waiting for her husband to go for a movie but he comes home fully drunk, scolds her and asks her to bring dinner. He throws the rice on her face. He says he can't take them to the movie and if she wants she can ask her father to take them to the movie. She weeps.

Part five discusses issues of dowry. It is titled 'ideal wedding'. One girl talks about her dreams about her wedding. The next session shows her wedding day. Bride's parents and bride grooms parents are having some arguments. Bride groom's parents demand more dowries (apart from the gold and land property which they have already given). Bridegroom's parents 
won't allow the marriage to happen unless their demands are met. The girl is in her wedding dress standing alone and weeping.

Part six is titled as 'ideal family'. One girl talks about her dreams about her married life. She prefers nuclear family, just her husband and her and wants to continue her job after marriage too. Both will take the decisions together and will go for vacation every year. She wants children only after two years - a boy and a girl. The next session shows the couple waiting for the doctor's report. In between, the husband's mother is shown sitting in the easy chair and saying "this family has the history of only male children. Did you come to break that tradition?" Husband is trying to convince his wife that she will have to abort the child. He can't disobey his mother and make her unhappy. She collapses down and cries.

The last part titled as 'ideal marriage and ideal life' discusses family issues, ego problems. One girl talks about her married life - she wants to continue with her job after marriage, family decisions will be taken together, she wants kids only after two years. In the next session, the wife is sitting in the sofa having tea. Suddenly husband comes drunk and scolds her for not putting money into his credit card. He says he was insulted in front of his friends in the bar as there was no money in the credit card. He threatens that he will make her resign and sit at home if she doesn't obey him.

The target audience was women - to be precise, middle class women because the film is screened in women's colleges and the population from the lower castes and classes in higher educational institutions is still very poor. The nature of these issues dealt in here are also very middle class in nature educational stress, dowry (the issue of dowry crept into lower castes very recently), etc. The female characters - their dressing style, family background, etc. - shown in the pictures are also very much representative of the middle class.

None of the issues discussed here addresses issues of caste, class, religion, sexuality and the like in the film. The silence and absence of such issues are very obvious. It also reflects the general absence of such issues in the mainstream as well as governmental discourses. Similarly it portrays the established notions of family, marriage and married life. It portrays 'nuclear family' with husband, wife and two children - one boy and one girl as the ideal family. The issues dealt here are just a replica of the issues dealt by the autonomous women's organizations in the 1980s. For instance, in the 80s, organizations like Bodhana, Prachodana, Anweshi, Manushi, etc have intervened in issues of sexual exploitations, domestic violences, dowry issues, and female foeticide and so on. However, the caste, class, religious and sexuality aspects of such issues were absent in their approach. They looked at 'women' as a homogenous entity with common issues and concerns.

The fact that it is screened only in women's colleges also is intriguing and interesting. It raises certain questions like - is gender issues only pertaining to women? Why men are not part of it? How the state is deploying 'gender' as a category? A careful observation will indicate the fact that the 'women' 90 
middle-class, educated, modern - central to the gender discourse possess the same characteristics as the women who is central to both the mainstream feminist discourse as well as the governmental discourse. The history of this 'women' can be traced back to the community Reformism of the late 19th early 20 th century.

\section{Problematizing the Category 'women'}

The late 19th - early 20th century was a transitional stage in the history of Kerala. The intolerance towards the established customs and ways of life was becoming visible by the late 19th century. The newly educated elite men found most of the practices especially the order of jati in which the social status of a person is decided by the caste or community into which he is born - barbaric. In its place a new order of gender is being roposed in which the division is made on the basis of their biological sex i.e., Man and Woman as 'gender' seemed more apparent and concrete. ${ }^{6}$

In the new order of gender, each individual is believed to acquire certain capacities and qualities at birth. It is believed that except certain qualities like intelligence and humility - 'male/female distinctions do not apply to intelligence and humility ${ }^{7}$ - qualities like modesty, love, affection, innocence, compassion, courage or will power are determined by the sexual endowment of the body as male or female. ${ }^{8}$ It led to the clear cut division of the public/private spheres with public the man's domain and the private/domestic woman's. Man, with his 'naturally' given qualities like physical strength and will power was projected as the bread-winner of the family. It was his duty to earn money for the family and thus support it. While, women with their 'naturally' given qualities like affection, modesty, generosity and tenderness were considered to be fit as the mistress of the Home:

Considering the physical and mental make-up of women and other natural talents for home-making, it may be readily understood that the goddess Nature has shaped them to be Potentates of Home. ${ }^{9}$

However, the well-being of the family and therefore the society is considered to be dependent upon complementary relation of Man and Woman.

Education was considered unavoidable in the development of the qualities and capacities acquired at birth. An ideal woman is one who is educated,

\footnotetext{
${ }^{6}$ Devika J. 2007. En-gendering Individuals: The Language of Re-forming in Twentieth Century Keralam. Hyderabad. Orient Longman 35.

7 Ayyappan, Parvathy. 2005. On Womanly Duty. In J. Devika (ed.) Gender and Early Writings of Malayalee Women. Kolkata. Stree Publication. 159.

${ }^{8}$ Devika J. 2007. En-gendering Individuals: The Language of Re-forming in Twentieth Century Keralam. Hyderabad. Orient Longman.

${ }^{9}$ Meenakshi Amma, K. K. 1924/2005. Nair Women and the Home. In J. Devika (ed.), Her-Self: Gender and Early Writings of Malayalee Women, 88-92. Kolkata: Stree.
} 
modern and possesses womanly virtues like modesty or compassion and performs her womanly duties which include: household work, taking care of children, instilling in them good qualities like generosity, kindness and godfear and getting them rid of superstitions, taking care of other old members of the family, attending to the needs of the husband, serving him with devotion and love and making him happy and comfortable. ${ }^{10}$

The economic depression of 1930s made it difficult for middle-class families just to depend entirely upon the husband's income and demanded the economic participation of women as well. Most of the articles written by women authors during that period urge women to take part in income generating jobs. And this was essentially considered part of womanliness:

Attending to the needs of husband caring for and training of children and other such holy tasks will fall within the womanly Duty: the obligation to help the community economically through efficient home management. The women, who are the goddess of wealth, must clear the way towards the uplift of the community ... Once the house work is done, the rest of the day must not be spent in gossip. It must be devoted to the generation of wealth through productive crafts ... they should engage in lucrative trades like sewing, spinning, weaving, mat-making, etc. ${ }^{11}$

However, it's the leisure time during which they were asked to do other works as the prime duty of a woman is to be a good housewife and a good mother. Her involvement in income generating works is just a supplementary work to support the income of the family.

The middle-class dominant caste model of man as the bread-winner and woman as the home-maker (house-wife) wasn't there among working class people till the mid-20th century. In most of the houses, it was the women who earned more and supported the family. These women had more freedom and mobility compared to the middle-class woman. The gender division of labour was also not true. Men from the lower class/caste used to do work which were usually considered as 'womanly'. Towards the 1940s and 50s, the middleclass values, norms and roles started getting infiltrated into their notions of family, sexuality or domesticity. The introduction of minimum wage and the adoption of male bread-winner have all facilitated this change. Such laws assumed women's primary role as housewives and their role as workers as only supplementary. ${ }^{12}$

\footnotetext{
${ }^{10}$ See Ayyappan, Parvathy. On Womanly Duty; K. Chinnamma. The Place of Women in Education and K. K. Meenakshi Amma. Nair Women and the Home. In J. Devika (ed.) 2005. Her-Self: Gender and Early Writings of Malayalee Women. Kolkata. Stree Publication.

${ }^{11}$ Meenakshi Amma, K. K. 1924/2005. Nair Women and the Home. In J. Devika (ed.), Her-Self: Gender and Early Writings of Malayalee Women, 88-92. Kolkata: Stree.

${ }^{12}$ Lindberg, Anna. 2005. Modernization and Effeminization in India: Kerala Cashew Workers Since 1930. Leifsgade. NIAS Press.
} 
The first generation of feminists endorsed such ideals of womanhood and manhood. Even when they demanded employment for women and their right to participate in political struggles, they didn't question the gender division of labour. Household work, caring of children and the like were considered as womanly duties. Besides, even when they demanded for employment opportunities, only jobs that would fit womanly nature were demanded. Professions like police, army, were considered unwomanly. ${ }^{13}$

The issues that most of these women's organizations projected as women's issues were mainly middle-class issues - the problem of unemployment of educated women, how to take care of children, how to manage both household work and other jobs, how to involve in income generating jobs, house management and so on. A number of women mostly from the lower caste/class were involved in industrial labour - cashew factory, coir factories, agricultural and artisanal labours - were facing many problems - low wages, unhygienic work conditions, sexual abuses and long working hours. However, none of these issues found place in the 'women's issues'. The middle-class nature and its protective mentality toward 'other' women continued among the second generation of feminists too. The main advocates of women's movement in $80 \mathrm{~s}$ and $90 \mathrm{~s}$ were mainly from the middle-class dominant caste groups.

The undemocratic nature of the mainstream feminism had been one of the criticisms pointed out by many of the feminist activists from marginal groups. While the Dalit, Muslim feminisms addressed caste, class and religious issues, sex-worker's movement and the sexual minority movements had to address not only caste, class and religious issue but also issues of sexuality or morality which were hardly welcomed by the mainstream feminists. The sex worker's movement was attacked by mainstream calling it as an attempt of the capitalists and forces of globalization to commodify women's body and sell it. According to them such attempts will result in sexual anarchy.

The middle-class nature and its protective mentality of the mainstream feminism took a different nature and form in the mid-90s. With the increased interest in women's issues in the global level in the 90s and with the neoliberal approach to development, women became the focus of the developmentalist agenda. Unlike before, where women were considered as mere beneficiaries of welfare programmes, the new development approach sees women as the agents of social change and development. The 'women' who is the target of these programmes are indeed the lower caste/lower class groups i.e. the accepted marginals. In Kerala, the formation of Development of Women and Child in Rural Areas; Kudumbashree Mission (1999) - the women centered poverty alleviation programme; Integrated Women's Empowerment Programme (2001) and Kerala State Women's Development

${ }^{13}$ Chandy, Anna. 2005. On Women's Liberation. In J. Devika (ed.) Her-Self: Gender and Early Writings of Malayalee Women. Kolkata. Stree Publication.125. 
Corporation (1998) were intended for the social and economic development of women belonging to the BPL (Below Poverty Line) families.

While the 1980s and 90s have seen the emergence of autonomous women's organizations, mid 90s have witnessed feminist engagement with different socio-economic development sectors, agencies and NGOs. We can also see their direct involvement with the government's developmental projects, Kudumbashree, SHG (Self-Help Groups) and gender training programmes for empowering and uplifting the poor women. It's interesting to note that the category 'women' is different from the Malayalee women mostly in terms of the class difference. However, they conform to gender norms and heterosexuality and roles like wives and mothers.

\section{Translating Gender: Questions of Power and Representation}

Unarthupattu, as it can be seen, reaffirms the existing notions of gender relations and gender roles. Though the programme was to create gender awareness among people, it does not question the established notions of femininity and gender roles. All the women portrayed in the programme conforms to the existing gender roles and are portrayed as weak, helpless, fragile and in need of help. Thus, ignoring the political possibilities gender as a concept brought in to the academic discourse. The whole programme is based on the presumed binary between man/woman and feminine/masculine. The discussion was only on female issues thus translating 'gender' as 'women'. The video excludes caste, religious, sexuality issues. Thus, the issues shown here conform to the exclusive representational politics of the mainstream. Translating gender as women therefore becomes a strategic way to reaffirm the existing norms and ideologies. According to Judith Butler (1990: 5), the construction of the category of women as a coherent and stable subject is an unwitting regulation and reification of gender relations.

To conclude, there is an urgency to look into politics of identity and representation and to critique such categories of identity whether in the feminist discourse or governmental discourse which 'contemporary juridical structures engender, naturalize and immobilize' (Butler 1990: 5) and to question and challenge the construction of such fixed and stable categories as the subjects of feminism.

\section{References}

AJITHA, K. 1990. Reminiscences from Wynad. In Ilina Sen (ed.), A Space within the Struggle: Women's Participation in People's Movements. 1924. New Delhi: Kali for Women.

ARunimA, G. 2003. There Comes Papa: Colonialism and the Transformation of Matriliny in Kerala, Malabar, c.1850-1940. New Delhi: Orient Longman.

AyYAPPAN, PARVATHY. 2005. On Womanly Duty. In Devika (ed.), Her-Self: Gender and Early Writings of Malayalee Women. 159-165. Kolkata: Stree. 
BAKER, MONA. (ed.) 2010. Critical Readings in Translation Studies. London: Routledge.

BHARADWAJ, RESHMA. (ed.) 2004. Mithyakalkku Appuram: Swavargalaingigata Keralattil. Kottayam: D. C. Books.

BUTLER, JUDITH. 1990. Gender Trouble: Feminism and the Subversion of Identity. New York: Routledge.

Bygnes, SuSANNE. 2005. Questioning Modernity and Development: A Qualitative Inquiry on Women's Emancipation in Kerala, India. Host: University of Bergen. PhD thesis.

CHANDRIKA, C. S. 2000. Keralattile Streemunnettangalude Charitram. Trissur: Kerala Sahitya Academy.

Chandy, Anna. 2005. On Women's Liberation. In Devika (ed.), Her-Self: Early Writings on Gender by Malayalee Women. 109-134. Kolkata: Stree.

Chatterjee, Partha. 2001. The Nationalist Resolution of the Women's Question. In Gregory Castle (ed.), Postcolonial Discourses: An Anthology. 233-253. United Kingdom: Blackwell Publishers.

ChInnAmma, K. 2005. The Place of Women in Education. In Devika (ed.), Her-Self: Gender and Early Writings of Malayalee Women. 29-36. Kolkata: Stree.

Chinnammalu Amma V. K. 2005. The Place of Women in Society. In Devika (ed.) Her-Self: Gender and Early Writings of Malayalee Women. 75-82. Kolkata: Stree.

DEVIKA, J. 2001. Streevadam. Kottayam: D. C. Books.

DEVIKA, J. (trans. \& ed.) 2005. Her-Self: Gender and Early Writings of Malayalee Women. Kolkata: Stree.

DEVIKA, J. and Mini SuKUMAR. 2006. Making Space for Feminist Critique in Contemporary Kerala. In Economic and Political Weekly (Oct 21). 44694475.

DEVIKA, J. 2007b. En-gendering Individuals: The Language of Re-forming in Early Twentieth Century Keralam. Hyderabad: Orient Longman.

DEviKA, J. 2007c. Being Woman and Marginal in Contemporary Kerala. Tapasam (Jan-April). 490-500.

GEETHA. 2005. Streevadattinte Kerala Parisaram. Thiruvanantapuram: Maitri Books.

INDIRA. 2005. Manushiyekkurichutanne. Mathrubhumi Azhchapatippu (Nov 27-Dec 3). 38-41.

JAKOBSON, ROMAN. 1959/2004. On Linguistic Aspects of Translation. In Venuti (ed.), The Translation Studies Reader. 138-43. London and New York: Routledge.

JAMILA, NALINI. 2005. Njan Laingikattozhilazhi: Nalini Jamilayude Aatmakatha. Kottayam: D. C. Books. 
JosePH. K. J. 2011. Interview with C. K. Janu. Maricchittilla Njan. Pachakkutira (August). 4-12.

Kalyani Amma, C. P. 2005. The Craze for Imitation. In Devika (ed.), HerSelf: Gender and Early Writings of Malayalee Women. 37-42. Kolkata: Stree.

LINDBERG, ANNA. 2005. Modernization and Effeminization in India: Kerala Cashew Workers since 1930. Copenhagen: Nordic Institute of Asian Studies (NIAS).

MeEnAKSHI AMMA, K. K. 2005. Nair Women and the Home. In Devika (ed.) Her-Self: Gender and Early Writings of Malayalee Women. 88-92. Kolkata: Stree.

MENON, DEVAKI. 2004. Sahayatrika: Chila Anubhavapadangal. In Bharadwaj (ed.), Mithyakalkku Appuram: Swavargalaingigata Keralattil. 20-35. Kottayam: D. C. Books.

NAYAK, NALINI. 1990. The Kerala Fisher Worker's Struggle. In Ilina Sen (ed.), A Space within the Struggle: Women's Participation in People's Movements. 141-159. New Delhi: Kali for Women.

SEN, IlinA. (ed.) 1990. A Space within the Struggle: Women's Participation in People's Movements. New Delhi: Kali for Women.

VenUti, LAWRENCE. 2008. The Translation Studies Reader. New York: Routledge. 